\title{
Research on Risk Control under the Background of Electricity Futures Market
}

\author{
Suyuan Chang ${ }^{1, *}$, Dunnan Liu' ${ }^{1}$, and Xiaoyu $\mathrm{Li}^{1}$ \\ ${ }^{1}$ North China Electric Power University, Beijing, 102206, China
}

\begin{abstract}
In the process of electricity marketization, the electricity futures market is an effective means to avoid the risk of electricity price fluctuations. Based on the background of the electricity futures market, this article first analyzes the physical and market factors of the price fluctuation risk in the electricity market; then, it studies the principle and implementation effects of the power futures hedging function; finally, the manufacturer's strategy of hedging based on the price difference between the spot price of electricity and the price of forward contracts has been studied in detail. This article believes that the electricity futures market can effectively hedge the spot market risk, and hedging strategies based on the difference between the spot price and the forward price are better.
\end{abstract}

\section{Introduction}

The establishment of the electricity futures market is an important part of the electricity marketization reform. The accelerated deregulation of electricity prices has exposed large-scale electricity market participants to the risks of price uncertainty and lack of price expectations. The futures market is an effective way to hedge spot price fluctuations ${ }^{[1]}$.

The foreign electricity futures market has a history of more than 20 years. The European market is the earliest power futures market in the world. The types of futures contracts mainly include Power Base, Power Peak and CFDs ${ }^{[2]}$. European and American electric power futures contracts have matured and are characterized by regional and cash settlement ${ }^{[3]}$. Japan officially launched the first electricity futures in September 2019, and its electricity improvement process and the measures are very similar to China's new round of electricity reforms, which has played an important role in China's electricity reform ${ }^{[4]}$.

Previous literature has also studied the risk control strategies of electricity futures, but it is mainly a hedging strategy based on the basis between the electricity futures price and the spot price, which has a large basis risk, so this paper proposes a new hedging strategy. This paper conducts research based on the risk control strategies of electricity futures. First of all, the power market price fluctuation risk is studied from multiple angles. Then, it analyzes how power futures can hedge the risk of power price fluctuation through hedging and the influencing factors of the hedging effect. Finally, a hedging strategy based on the difference between the spot price of electricity and the price of forward contracts was established.

\section{Risk Control Analysis of Electricity Futures}

\subsection{Risk analysis of price fluctuations in the electricity market}

\subsubsection{Physical reasons for price fluctuations}

The big fluctuations in electricity prices are inseparable from the special physical properties of electricity.

Unlike tangible commodities, the three major characteristics of electricity - stable production, variable demand, and difficult storage - determine that market prices will always be volatile and highly unpredictable. To put it simply, the power plant's machinery must be produced 24 hours a day, but the load on the power grid is constantly changing with time and space. With the existing technical conditions, it is not economical to store electricity, so the redundant electricity can only be wasted "for nothing."

\subsubsection{Market reasons for electricity price fluctuations}

With the rapid advancement of the new round of power reforms, significant progress has been made in China's power system reform, and the power market is moving towards a fully competitive market. In a market competitive environment, electricity prices will become sensitive, subject to changes in supply and demand and other factors, and will easily fluctuate significantly. On September 26, 2019, an executive meeting of the State Council was held to decide to improve the on-grid

\footnotetext{
* Corresponding author: 18813010368@163.com
} 
electricity price formation mechanism for coal-fired power generation, promote market-based electricity trading, and reduce the cost of electricity for enterprises. The meeting pointed out that from January 1, 2020, the coal-electricity price linkage mechanism will be abolished, and the current benchmark on-grid electricity price mechanism will be changed to a "benchmark price + floating" market-oriented mechanism. This policy adjustment will accelerate the construction of electricity marketization. In the process of electricity marketization, electricity price fluctuations are its main characteristics.

There is a natural asymmetry in the supply and demand of electricity, coupled with the rapid development of renewable energy power generation in recent years (the power output is uncontrollable), and the fully competitive spot market is prone to extreme prices [5].

\subsection{Hedging strategies for electricity futures}

The electricity futures market is an effective way to hedge spot price fluctuations.

One of the most basic functions of futures is risk aversion, and the main strategy of risk aversion is hedging. Electricity companies can avoid electricity price risks through hedging of electricity futures. That is to say, in order to prevent electricity prices from rising, electricity purchasers can buy the same amount of electricity futures (long positions) in the electricity futures market and fix the electricity purchase price at the contract price to avoid the risk of electricity price increase; in order to prevent the spot market electricity price from falling, power generation companies can sell the same amount of electricity futures (short positions) in the electricity futures market and fix the electricity sale price to the contract price to avoid the risk of electricity price decline.

\subsubsection{The principle of hedging}

Futures hedging refers to using the futures market as a place to transfer price risk and using futures contract as a temporary substitute for buying and selling commodities on the spot market in the future, and a trading activity that insures the price of the sale of goods after preparation for buying now or goods that need to be bought in the future. The basic characteristic of hedging is that in the spot market and the futures market, the same type of goods are simultaneously traded in the same quantity but in opposite directions. In other words, when buying or selling physical goods, they are sold or bought on the futures market. Into the same amount of futures, after a period of time, when the price change makes a profit or loss in spot trading, the profit or loss on futures trading can be offset or compensated. So as to establish a hedging mechanism between the "current" and "future", and between the near-term and long-term, in order to reduce the price risk to a minimum.

The reason why hedging can avoid price risk is firstly because the futures price trend of the same commodity is consistent with the spot price trend, because they will be affected and restricted by the same economic factors in the same market environment. Therefore, investors can take opposite actions to hedge in two markets, transferring price risk out. Secondly, the prices of the spot market and the futures market tend to be the same as the expiry date of the futures contract approaches. This is because of the existence of a futures delivery system. If the prices of the two are not close when the delivery is near, risk-free arbitrage will occur opportunity, and the existence of arbitrage transactions eventually made futures prices and spot prices more consistent.

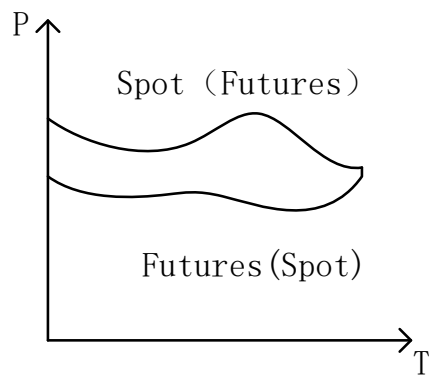

Fig. 1. Relationship between spot electricity prices and futures prices.

\subsubsection{Analysis of influencing factors on the effect of hedging of power futures}

Take the power purchaser's risk avoidance through the electricity futures market as an example to explain the influencing factors of the hedging effect. Suppose that the power purchaser plans to purchase $1 \mathrm{MWh}$ of electricity in the spot market at time $t+1$. In order to prevent the price of electricity in the spot market from rising, the purchaser purchases $\alpha$ MWh power futures at time $t$ and sells $\alpha$ MWh power futures at time $t+1$ to close the position. The electricity purchase income of the electricity purchase users is shown below:

$$
\begin{aligned}
& R=-p_{t+1}+\alpha\left(p_{f, t+1}-p_{f, t}\right)= \\
& -\left[\alpha p_{f, t}+\left(p_{t+1}-\alpha p_{f, t+1}\right)\right]
\end{aligned}
$$

Where, $\alpha$ is the hedging ratio, $p_{t+1}$ is the spot electricity price at time $t+1$, and $p_{f, t}$ and $p_{f, t+1}$ are the electricity futures price at time $t$ and $t+1$, respectively.

It can be seen from the income formula of power purchasers that the effect of hedging is affected by two factors, the basis difference and the hedging rate.

\section{(1) Hedging rate}

The traditional hedging ratio is 1 , but with the development of the hedging theory, the optimal hedging rate depends on the purpose of the hedging transaction and the correlation between the electricity spot and futures prices. Investment theory believes that hedging by traders is actually a combination of assets in the spot and futures markets. The hedger determines the trading positions in the spot and futures markets based on the expected return of the portfolio investment and its variance. Minimize return risk or maximize utility. The theory of portfolio investment believes that the 
proportion of hedgers in the futures market can be selected.

\section{(2) Basis}

The basis difference, also known as the premium, refers to the difference between the spot price of a specific commodity at a specific time and place and the futures price of the commodity in the futures market, that is, the basis difference $=$ spot price-futures price. When the basis is negative, it is also called spot discount; when the basis is positive, it is also called spot premium.

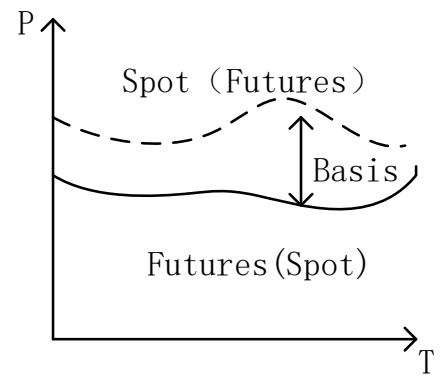

Fig. 2. Basis chart.

In the above example, assuming $\alpha=1$, we get the following formula:

$$
\begin{aligned}
& R=p_{f, t+1}-p_{f, t}+p_{t}-p_{t+1}-p_{t}=\left(p_{t}-p_{f, t}\right)- \\
& \left(p_{t+1}-p_{f, t+1}\right)-p_{t}=B_{t}-B_{t+1}-p_{t}=-\Delta B-p_{t}
\end{aligned}
$$

In the formula, $B$ represents the basis. If $\Delta B=0$, the hedging strategy of the power purchaser completely avoids the risk of price fluctuations in the spot market. Therefore, the effect of hedging depends on changes in the basis, and the smaller the basis, the better the hedging effect.

The essence of hedging is to transform the risk of hedging into basis risk. The factors that affect the risk of power basis are more complicated, mainly including the remaining term of the power futures contracts and the correlation between the spot price of electricity and the futures price. The longer the remaining period, the greater the possibility that the electricity futures price and the spot price will diverge, and the greater the basis risk. Therefore, cash settlement of electricity futures is considered instead of electricity spot delivery to eliminate the remaining period of electricity futures. The higher the correlation between the electricity spot price and the futures price, the smaller the basis risk. Therefore, in general, the effect of direct hedging of electricity futures is better than cross-hedging.

\section{Analysis of power futures risk control strategies based on spreads}

\subsection{Risk Analysis of Opening Electricity Market}

The prerequisite for avoiding the risk of price fluctuations in the spot market by hedging is that the spot price and the futures price have the same trend, and there is a co-integration relationship between the two. However, in the electricity market, the unstorability of electricity commodities has weakened the price relationship between electricity futures and spot, so that the price of expired futures contracts does not converge to spot prices. As a result, the hedging of the power market faces a large basis risk.

In the open electricity market environment, forward contracts play an important role in maintaining the safety and stability of the electricity market with their transaction prices and electricity stability, which account for most of the actual load electricity in the entire market. On the surface, there is no risk in the forward contract price itself, but because the forward contract electricity price is inelastic, during the delivery period, when the spot price rises beyond the forward price, the power generation manufacturer faces potential losses. Based on this, the subject of hedging by power generation companies is the difference between the spot price and the forward price. During the delivery period, the forward contract electricity price is fixed, and it will bear the potential losses caused by the increase in electricity prices during the delivery period. If generators can correctly determine the price trend, they can hedge a part of their losses by buying electricity futures and then selling electricity futures. This type of hedging strategy of power generation manufacturers is different from the conventional hedging strategy that takes the spot price of electricity as the target. Under this strategy, the difference between the spot price and the forward contract price is the basis for deciding whether to carry out hedging, and whether the basis difference between the spot and futures prices is stable is the basis for whether hedging can be achieved.

\subsection{Analysis of hedging strategies based on spreads}

The hedging strategy based on the difference between the spot price and the forward contract price is as follows:

Let the prices of the spot market, forward contract market, and futures market at time $t$ and $t+1$ during the delivery period be $p_{t}, p_{\mathrm{f}, t}, p_{F, t}, p_{t+1}, p_{f, t+1}, p_{F, t+1}$ respectively. The difference between the spot price and the forward contract price of the power generation company at time $t$ and time $t+1$ are shown below:

$$
\begin{aligned}
-\eta_{t} & =p_{t}-p_{f, t} \\
\eta_{t+1} & =p_{t+1}-p_{f, t+1}
\end{aligned}
$$

Potential losses for power generation companies are $-\eta_{t},-\eta_{t+1}$ respectively. Because the forward contract price is fixed and does not change, that is, $p_{f, t}=p_{f, t+1}$, the difference between the time $t$ and the time $t+1$ is shown below:

$$
\begin{aligned}
& \Delta \eta=\eta_{t+1}-\eta_{t}=\left(p_{t+1}-p_{f, t+1}\right) \\
& -\left(p_{t}-p_{f, t}\right)=p_{t+1}-p_{t}
\end{aligned}
$$

If $\Delta \eta>0$, the price difference between the spot price and the forward contract price is enlarged, and the potential loss is enlarged; if $\Delta \eta<0$, the price difference between the spot price and the forward contract price is reduced, and the potential loss is reduced. Therefore, 
power generation manufacturers can judge whether to carry out hedging through the difference between the spot price of electricity and the price of electricity forward contract.

\subsubsection{Analysis of hedging strategies with widening spreads}

At $p_{f, t+1}<p_{t}<p_{t+1}$, according to the cointegration relationship between the electricity futures market and the electricity spot market price, there is $p_{F, t}<p_{F, t+1}$. The spot electricity price is greater than the forward contract price, the generator is in a potential loss state, and the loss trend is expanding. The change in the price difference is shown below:

$$
\begin{aligned}
& \Delta \eta=\eta_{t+1}-\eta_{t}=\left(p_{t+1}-p_{f, t+1}\right)- \\
& \left(p_{t}-p_{f, t}\right)=p_{t+1}-p_{t}>0
\end{aligned}
$$

At this time, the power generation manufacturer can buy multiple hedging, and buy and sell in the futures market at time $t$ and $t+1$ respectively. The profit is shown below:

$$
\Delta p_{F}=p_{F, t+1}-p_{F, t}
$$

Assuming that there are no transaction costs, gains in the futures market will be able to hedge potential losses in the electricity forward contract market. The gain (loss) of the entire process is shown below:

$$
\begin{aligned}
& \Delta=\Delta p_{F}-\Delta \eta=\left(p_{F, t+1}-p_{F, t}\right)- \\
& \left(p_{t+1}-p_{t}\right)=\left(p_{t}-p_{F, t}\right)-\left(p_{t+1}-p_{F, t+1}\right)
\end{aligned}
$$

\subsubsection{Analysis of hedging strategies with reduced spreads}

When $p_{f, t+1}<p_{t+1}<p_{t}$, the change in the spread is shown below:

$$
\begin{aligned}
& \Delta^{\prime} \eta=\eta_{t+1}-\eta_{t}=\left(p_{t+1}-p_{f, t+1}\right) \\
& -\left(p_{t}-p_{f, t}\right)=p_{t+1}-p_{t}<0
\end{aligned}
$$

There is $p_{F, t+1}<p_{F, t}$ in the futures market. At this time, the power generation manufacturer can carry out short selling hedging on the electricity futures market, and sell and then buy electricity futures. The profit is shown below:

$$
\Delta^{\prime} p_{F}=p_{F, t}-p_{F, t+1}
$$

The gain (loss) of the entire process is shown below:

$$
\begin{aligned}
& \Delta^{\prime}=\Delta p_{F}+\Delta \eta=\left(p_{F, t}-p_{F, t+1}\right)+\left(p_{t+1}-p_{t}\right) \\
& =\left(p_{t+1}-p_{F, t+1}\right)-\left(p_{t}-p_{F, t}\right)
\end{aligned}
$$

According to the above analysis, it can be concluded that the power generation manufacturer can conduct long or short selling hedging transactions based on the difference between the spot price of electricity and the price of the electricity forward contracts to offset the potential losses of the electricity forward contracts.

In addition, it can be seen from the above formula of the gain (loss) of the whole process that the hedging effect based on the difference between the spot price of electricity and the price of electricity forward contracts as the target still depends on the basis changes between the spot price of electricity and the futures price.

\section{Conclusion}

Aiming at the risk of price fluctuations in the electricity market, this paper studies the risk control strategies for electricity futures. Firstly, it analyzes the risk of price fluctuations in the electricity market, and studies the physical and market factors that cause electricity price fluctuations. Then it studies the hedging function of electricity futures, from its principles and influencing factors of hedging effects. Finally, based on the potential risks of power forward contracts, a hedging strategy based on spreads is established to hedge risks.

\section{Acknowledgement}

State Grid Beijing Electric Power Company Policy Research Project (Research on the Power Market in Beijing in the Construction of "Three Types and Two Grids").

\section{References}

1. R. Jing. China Power Enterprise Management, Construction of Electricity Futures Exchange Breaking the Deadlock in the Regional Electricity Market, 1, 36-39, (2018).

2. M. He, J. Wang. Price Theory and Practice, Foreign Electric Power Futures Market Development Experience and Its Enlightenment to China, 12, 7881, (2018).

3. Z.X. Lu, W. Huang. China Securities Futures, Overview of Global Power Futures Market and Analysis of Contract Features, 5, 25-29, (2018).

4. Xiangnenghui Studio. How to avoid risks when Japan's electricity futures are listed? http://shoudian.bjx.com.cn/html/20190920/1008548. shtml, 1(2019).

5. Y.H. Xing, M.L. Zhang, S.Q. Liu, et al. Electrical Engineering Society, Discussion on the construction path of China's electric power financial market, 135-139, (2018). 